\title{
Átraskanir og átröskunarmeðferð á Landspítala
}

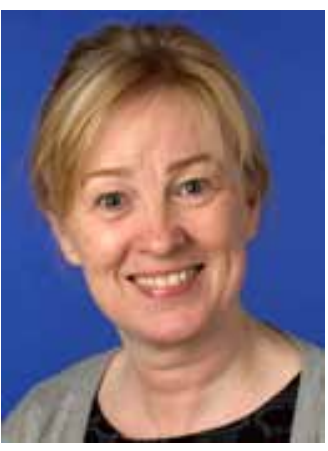

Guơlaug Porsteinsdóttir geðlæknir

gudlthor@landspitali.is

Göngudeild geðsviðs átröskunarteymi Hvítabandi

Skólavörðustíg 37 Landspítali, 101 Reykjavík

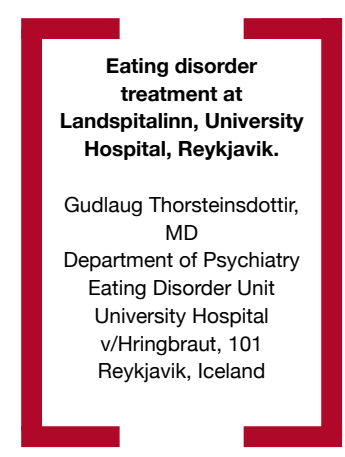

Átraskanir eru geðsjúkdómar sem einkennast af sjúklegum ótta við mat og hræðslu við að pyngjast eða missa stjórn á mataræði og verða feit(ur). Pegar talað er um átraskanir í daglegu tali tengja flestir pær við lystarstol (anorexia nervosa) og sjá fyrir sér horaðar, veiklulegar ungar konur sem virðast lifa á loftinu. Flestum er pað óskiljanlegt hvernig vannærður einstaklingur getur neitað sér um að borða pegar nóg framboð er af mat. En átraskanir eru fleiri en lystarstol og í heimi fræðimanna er deilt um flokkun átraskana. Sumir vilja aðeins hafa eina átröskunargreiningu, enda sé fleira sem sameinar átraskanir en aðgreinir pær. ${ }^{1}$ Lystarstol og lotugræðgi séu aðeins sitt hvor hliðin á sama teningi. Раð sem viðhaldi átröskuninni, hvaða nafni sem hún nefnist, sé að minnsta kosti eitt af eftirtöldu: fullkomnunarárátta, lágt sjálfsmat, ópol gagnvart vanlíðan og erfiðleikar í samskiptum. Bent er á óstöðugleika greiningar, margir byrji til dæmis með lystarstol sem próast síðar yfir í lotugræðgi, ${ }^{2}$ greiningarskilmerkin séu fremur stíf og flestir sem leiti meðferðar lendi í raun í „afgangsflokknum“; ódæmigerðar átraskanir. Aðrir vilja flokka átraskanir með kvíðasjúkdómum og benda á líkindi við fælni eða áráttupráhyggjuröskun. Beðið er í ofvæni eftir DSM 5, sem kemur út 2013, en ljóst er að átraskanir verða áfram sérstakir sjúkdómar par sem helstu flokkar halda sér: lystarstol, lotugræðgi og ódæmigerðar átraskanir, en talsverðar breytingar verða á greiningarskilmerkjum sem og undirflokkum.

Átröskunarmeðferð á Íslandi sem pverfagleg teymisvinna er ný af nálinni miðað við löndin í kringum okkur. Átröskunarteymið á geðdeild Landspítala var stofnað 2001 og kom undirrituð að pví ásamt fleira starfsfólki á móttökugeðdeild 33 C. Teymið starfaði í prjú ár. Aðalástæða fyrir stofnun pess var skortur á sérhæfingu og samhæfðum meðferðarúrræðum fyrir sjúklinga með átraskanir á fullorðinsgeðdeild og vöntun á eftirfylgd. Mörgum fannst pó óparfi að hafa sérstakt átröskunarteymi á geðdeild og teymið rakst á ýmsar hindranir og hætti að taka við tilvísunum í lok árs 2003. Tilvísanir höfðu pá verið 51, 65 og 51 á ári. Meðallengd veikinda hjá skjólstæðingum var 8,3 ár, og margir höfðu áður verið í meðferð á geðdeild. Niðurstaða teymisins strax eftir fyrsta árið var að leggja til við stjórnendur að stofna dagdeild fyrir fimm sjúklinga með átraskanir, efla göngudeild og leggja til stöðugildi fyrir starfsemina. Um svipað leyti, eða árið 2002, voru stofnuð aðstandendasamtök sjúklinga með átraskanir, Spegillinn, og studdu pau við hið nýja teymi. Voru pau stofnuð í kjölfar andláts ungrar konu sem lengi hafði glímt við átröskun. Beittu pau sér mjög fyrir bættum meðferðarúrræðum og aukinni meðvitund almennings um átraskanir. Spegillinn hélt úti heimasíðu og forvarnarstarfi, en starfsemi peirra lagðist af um 2007.

En fleira gerðist árið 2002, pá var sampykkt eftirfarandi pingsályktunartillaga: Alpingi felur heilbrigðisráðherra að sjá til pess að pverfagleg pjónusta peirra sem hafa sérpekkingu á átröskunum verði sameinuð pannig að bjóða megi upp sérhæfða meðferð fyrir átröskunarsjúklinga á öllum aldri. Fjórtán alpingismenn og konur stóðu að tillögunni undir forystu Katrínar Fjeldsted læknis. Spegillinn og síðar sjúklingasamtökin Forma (starfaði 20052007) prýstu í kjölfarið mjög á yfirvöld að fylgja eftir tillögunni sem markaði tímamót. Sett var á laggirnar nefnd hjá landlækni sem skilaði álitsgerð í nóvember 2003 um hvernig pjónustunni væri best háttað. Par var meðal lagt til að stofnuð yrði „meðferðar-, fræðslu- og ráðgjafarmiðstöð“, sameiginleg fyrir börn og fullorðna að norskri fyrirmynd, og að pjónusta yrði veitt á göngudeild, dagdeild og sérhæfðu meðferðarheimili. Ekki hefur pað allt ræst en Jón Kristjánsson páverandi heilbrigðisráðherra gekkst síðar fyrir aukafjárveitingu til átröskunarmeðferðar á Landspítala og hóf núverandi teymi störf 1.2.2006. Fjöldi tilvísana í teymið hefur verið nokkuð svipaður á ári, eða um 83$103,10-15 \%$ sjúklinga greinast með lystarstol og 40-50\% með lotugræðgi, en aðrir með ódæmigerðar átraskanir. Meðferð fer fram á göngudeild og dagdeild og hefur legudögum vegna lystarstols á móttökugeðdeildum fækkað mjög mikið síðustu prjú ár. Meðferðin byggist á gagnreyndum aðferðum og í dag pykir sérhæfð átröskunarmeðferð sjálfsagður og ómissandi hluti af meðferðarúrræðum á geðdeild Landspítala.

Frekari upplýsingar um starfsemi átröskunarteymis geðdeildar er að finna á heimasíðu Landspítala.

\section{Heimildir}

1. Fairburn CG, Cooper Z, Shafran R. Cognitive behaviour therapy for eating disorders: a "transdiagnostic" theory and treatment. Behav Res Ther 2003; 41: 509-28.

2. Tozzi F, Thornton LM, Klump KL, et al. Symptom fluctuation in eating disorders: correlates of diagnostic crossover. Am J Psychiatry 2005; 162: 732-40. 